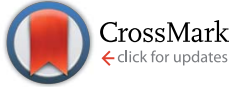

Cite this: RSC Adv., 2014, 4, 44124

Received 4th July 2014

Accepted 10th September 2014

DOI: $10.1039 / c 4 r a 06646 d$

www.rsc.org/advances

\section{Basicity-controlled synthesis of $\mathrm{Li}_{4} \mathrm{Ti}_{5} \mathrm{O}_{12}$ nanocrystals by a solvothermal method $\dagger$}

\begin{abstract}
Hiroyuki Kageyama, Yuya Oaki and Hiroaki Imai*
Spinel-type lithium titanate $\left(\mathrm{Li}_{4} \mathrm{Ti}_{5} \mathrm{O}_{12}\right)$ nanocrystals were synthesized at a low temperature with control of the basicity by a solvothermal method without any calcination processes. The Li-Ti-O precursor was produced under relatively high $\mathrm{pH}$ conditions $(\mathrm{pH}>11)$ in the initial stage. The spinel phase was then formed through delithiation and dehydration from the precursor by lowering the $\mathrm{pH}$ of the system $(\mathrm{pH}<$ 10). The direct synthesis of the $\mathrm{Li}_{4} \mathrm{Ti}_{5} \mathrm{O}_{12}$ nanocrystals was achieved through self-control of the basicity using a two-phase system of water-ethanol and toluene-oleic acid. The $\mathrm{Li}_{4} \mathrm{Ti}_{5} \mathrm{O}_{12}$ crystals were formed from the precursor by decreasing the basicity. The average size of the nanocrystals prepared by the onestep method was ca. $13 \mathrm{~nm}$, and the specific surface area was $158 \mathrm{~m}^{2} \mathrm{~g}^{-1}$. On the basis of the electrochemical measurement, the $\mathrm{Li}_{4} \mathrm{Ti}_{5} \mathrm{O}_{12}$ nanocrystals produced in a low-temperature solution system are applicable for an anode material of a lithium-ion rechargeable battery.
\end{abstract}

\section{Introduction}

In recent years, a wide variety of cathode and anode materials have been studied to improve the capacity and durability of rechargeable lithium-ion batteries. Spinel lithium titanate $\left(\mathrm{Li}_{4} \mathrm{Ti}_{5} \mathrm{O}_{12}\right)$ is a stable anode material having a reaction potential of $1.55 \mathrm{~V}\left(v s . \mathrm{Li} / \mathrm{Li}^{+}\right)$and a theoretical capacity of $175 \mathrm{~mA} \mathrm{~h} \mathrm{~g}^{-1}$ for lithium-ion batteries. This oxide is well known as zero-strain insertion material having high durability against the insertiondesertion of charge-discharge cycles. ${ }^{1-4}$ The size reduction of the crystalline particles is important for further improvement of the capacity and rate performance through expansion of the interface area for the electrochemical reaction and shortening of the distance for the lithium-ion diffusion. ${ }^{5}$ Thus, the nanosized particles, hierarchical structures and mesoporous frameworks of $\mathrm{Li}_{4} \mathrm{Ti}_{5} \mathrm{O}_{12}$ were reported to enhance the performance. ${ }^{6-11}$ However, calcination processes above $400{ }^{\circ} \mathrm{C}$ are required to produce the spinel structure, and their nanostructures would be degraded at high temperatures. ${ }^{8-16}$ In the current work, we directly synthesized the nanocrystals of $\mathrm{Li}_{4} \mathrm{Ti}_{5} \mathrm{O}_{12}$ in a solution system by controlling the basicity without any subsequent calcination processes.

Hydrothermal and solvothermal methods are useful for the synthesis of nanocrystals and hierarchical structures of various metal oxides. ${ }^{17-23}$ However, they generally have been hindered by problems such as controlling their chemical composition, size distribution and crystallinity. Particularly, exploration of

Department of Applied Chemistry, Faculty of Science and Technology, Keio University, 3-14-1 Hiyoshi, Kohoku-ku, Yokohama, 223-8522, Kanagawa, Japan. E-mail: hiroaki@ applc.keio.ac.jp; Fax: +81-455661551; Tel: +81-455661556

$\dagger$ Electronic supplementary information (ESI) available: Fig. S1 and S2. See DOI: 10.1039/c4ra06646d the optimum conditions for the synthesis of complex oxides is required. In previous works, alkali-earth titanium oxides having a stable perovskite structure $\left(\mathrm{BaTiO}_{3}, \mathrm{SrTiO}_{3}\right.$, and $\left.\mathrm{CaTiO}_{3}\right)$ and layered alkali titanium oxides $\left(\mathrm{Na}_{2} \mathrm{Ti}_{6} \mathrm{O}_{13}, \mathrm{KTi}_{8} \mathrm{O}_{16.5}\right.$, and $\mathrm{Cs}_{x^{-}}$ $\mathrm{Ti}_{2-x / 4} \square \square_{x / 4} \mathrm{O}_{4}$ ) were prepared through hydrothermal routes by adjusting conditions including temperature and $\mathrm{pH}^{24-29}$ Although $\mathrm{Li}_{2} \mathrm{TiO}_{3}$ was obtained by a hydrothermal process, the preparation of crystalline spinel $\mathrm{Li}_{4} \mathrm{Ti}_{5} \mathrm{O}_{12}$ has not been achieved without subsequent calcination. ${ }^{30,31}$ While the diffraction pattern assignable to $\mathrm{Li}_{4} \mathrm{Ti}_{5} \mathrm{O}_{12}$ was reported for a product obtained through a solvothermal process by Fattakhova et al., the structural analysis was insufficient and the preparation condition was ambiguous..$^{32}$ In recent papers, formation of the $\mathrm{Li}_{4} \mathrm{Ti}_{5} \mathrm{O}_{12}$ phase was achieved through a nonaqueous or supercritical synthesis without an annealing process. ${ }^{33,34}$ However, these methods required restricted conditions such as an inert atmosphere or high temperature and high pressure. Moreover, the $\mathrm{Li}_{4} \mathrm{Ti}_{5} \mathrm{O}_{12}$ prepared by the nonaqueous synthesis included $\mathrm{TiO}_{2}$ as an impurity, or $\mathrm{Li}_{2} \mathrm{TiO}_{3}$ appeared after annealing. Therefore, development of the aqueous-solution system for preparation of spinel-type $\mathrm{Li}_{4} \mathrm{Ti}_{5} \mathrm{O}_{12}$ is still important to produce its nanometric structure with a simple technique for various applications.

In present study, single-phase $\mathrm{Li}_{4} \mathrm{Ti}_{5} \mathrm{O}_{12}$ nanocrystals were directly obtained by a two-step solvothermal method (method I) or a one-step two-phase method (method II) as shown in Scheme 1. The basicity control after formation of the Li-Ti-O precursor was found to be essential for synthesis of the spinel crystal. The resultant $\mathrm{Li}_{4} \mathrm{Ti}_{5} \mathrm{O}_{12}$ crystals, $c a .13 \mathrm{~nm}$ in diameter, exhibited a good capacity as an anode material for lithium-ion batteries even without heat treatment. The cycle stability of the nanocrystals was greatly enhanced through improvement of 

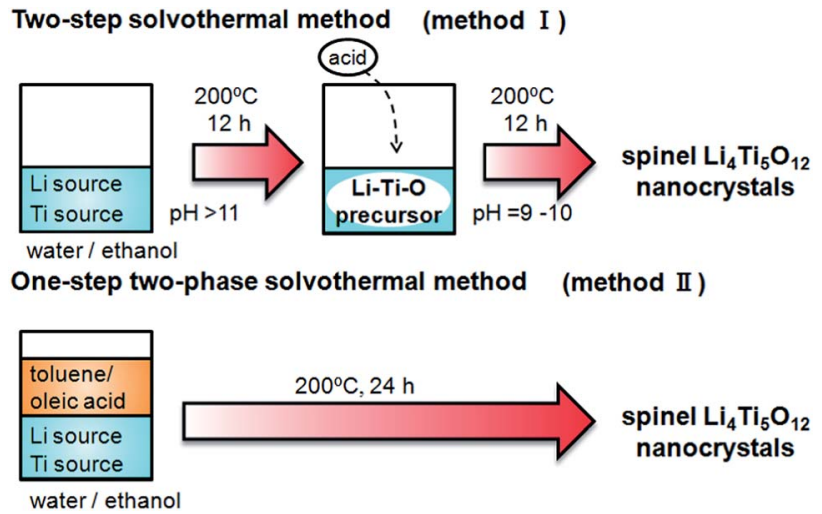

Scheme 1 Solvothermal methods for basicity-controlled syntheses of the $\mathrm{Li}_{4} \mathrm{Ti}_{5} \mathrm{O}_{12}$ nanocrystals.

the crystallinity by calcination. The basicity-controlled solvothermal technique would be useful for preparation of a wide variety of complex oxide materials.

\section{Experimental section}

The pH-controlled two-step solvothermal method (method I in Scheme 1) was examined as follows. All the reagents in the present work were used without further purification. A $1.0 \mathrm{~mol}$ $\mathrm{dm}^{-3}$ LiOH solution was prepared by dissolving $\mathrm{LiOH} \cdot \mathrm{H}_{2} \mathrm{O}$ (Kanto Chemical) in $20 \mathrm{~cm}^{3}$ of a mixture of purified water and ethanol (1/1 volume). Bis(ammonium lactate) titanium dihydroxide (Sigma-Aldrich) was mixed into the solution (molar ratio of Li/Ti: 10), and a white precipitate formed immediately. The first solvothermal process was carried out in a Teflon-lined stainless steel autoclave at $200{ }^{\circ} \mathrm{C}$ for $12 \mathrm{~h}$. After cooling to room temperature, the $\mathrm{pH}$ of the mixture was decreased to a value between 9 and 10 by the addition of $0.014 \mathrm{~mol}$ of acetic acid. The second solvothermal process was then carried out at $200{ }^{\circ} \mathrm{C}$ for $12 \mathrm{~h}$. The obtained precipitates were washed by ethanol and purified water and dried at $60{ }^{\circ} \mathrm{C}$ in air.

We directly prepared $\mathrm{Li}_{4} \mathrm{Ti}_{5} \mathrm{O}_{12}$ crystals using a basicitycontrolled two-phase solvothermal method (method II in Scheme 1). The same mixture of purified water and ethanol containing $\mathrm{LiOH} \cdot \mathrm{H}_{2} \mathrm{O}$ and bis(ammonium lactate) titanium dihydroxide as for the two-step method was used for the onestep two-phase method. Toluene $\left(20 \mathrm{~cm}^{3}\right)$ containing $32 \mathrm{mmol}$ of oleic acid (Wako Pure Chemical) and tert-butylamine (Wako Pure Chemical) was carefully poured to the water-ethanol mixture. The solvothermal treatment of the two-phase system was carried out at $200{ }^{\circ} \mathrm{C}$ for 12 or $24 \mathrm{~h}$. The obtained precipitates were washed by ethanol and purified water and dried at $60{ }^{\circ} \mathrm{C}$ in air.

The crystal phases were identified by X-ray diffraction (XRD: Rigaku MiniFlex II and Bruker D8 Advance) with CuK $\alpha$ radiation. Crystalline domain sizes $D_{(h k l)}$ are calculated by the Scherrer equation. The values of full width at half maximum (FWHM) were calibrated with a highly crystalline standard sample. The morphologies of particles were observed by a transmission electron microscope (TEM: FEI TECNAI-F20) operated at $200 \mathrm{kV}$. The specific surface area was measured by the $\mathrm{N}_{2}$-adsorption/desorption measurement (Shimazu Trister 3000). The electrochemical performance was measured with a beaker-type three-electrode cell. The working electrode was a slurry composed of $80 \mathrm{wt} \% \mathrm{Li}_{4} \mathrm{Ti}_{5} \mathrm{O}_{12}$ or other $\mathrm{Li}-\mathrm{Ti}-\mathrm{O}$ products, $10 \mathrm{wt} \%$ acetylene black carbon and $10 \mathrm{wt} \%$ polyvinylidene difluoride binder dispersed in $N$-methyl pyrrolidinone. The slurry was dropped on a Ni mesh and dried at $80^{\circ} \mathrm{C}$ in vacuum. A lithium metal was used for the counter and reference electrodes on a Ni mesh. The electrolyte was $1 \mathrm{~mol} \mathrm{dm}^{-3}$ of $\mathrm{LiClO}_{4}$ in ethylene carbonate and diethyl carbonate ( $1 / 1$ volume). The cell was assembled in an argon-filled glove box. Galvanostatic discharge-charge measurements were performed in a potential range between 1.0 and $2.7 \mathrm{~V} v$ s. $\mathrm{Li} / \mathrm{Li}^{+}$at room temperature. ${ }^{8}$

\section{Results and discussion}

\subsection{Basicity-controlled two-step solvothermal method (method I)}

The precipitate was obtained through the solvothermal reaction with lithium and titanium ions at a pH value over 11 in the first step. According to the XRD pattern (Fig. 1a), the product of the first step was the Li-Ti-O precursor, which was reported in previous works for hydrothermal synthesis of lithium titanates. ${ }^{\mathbf{8}, \mathbf{9}, 13,14,34-36}$ The $\mathrm{Li}-\mathrm{Ti}-\mathrm{O}$ precursor was deduced to be nominal cubic $\alpha-\mathrm{Li}_{2} \mathrm{TiO}_{3}$ due to the following reasons. The diffraction pattern of the intermediate phase was very similar to the XRD profile assigned to $\alpha-\mathrm{Li}_{2} \mathrm{TiO}_{3}$ by Laumann et al. ${ }^{36}$ Basically, two major diffraction peaks of (200) and (220) appear for $\alpha-\mathrm{Li}_{2} \mathrm{TiO}_{3}$ in the range of $2 \theta=10-80^{\circ}$. The spacings for $d_{(200)}$ of $\alpha-\mathrm{Li}_{2} \mathrm{TiO}_{3}, d_{(-133)}$ of monoclinic $\beta-\mathrm{Li}_{2} \mathrm{TiO}_{3}$, and $d_{(400)}$ of cubic $\mathrm{Li}_{4} \mathrm{Ti}_{5} \mathrm{O}_{12}$ are $0.2075 \mathrm{~nm}$ (ref. 36), $0.2075 \mathrm{~nm}$ (ICDD: 033-0831), and $0.2091 \mathrm{~nm}$ (ICDD: 049-0207), respectively. As shown in

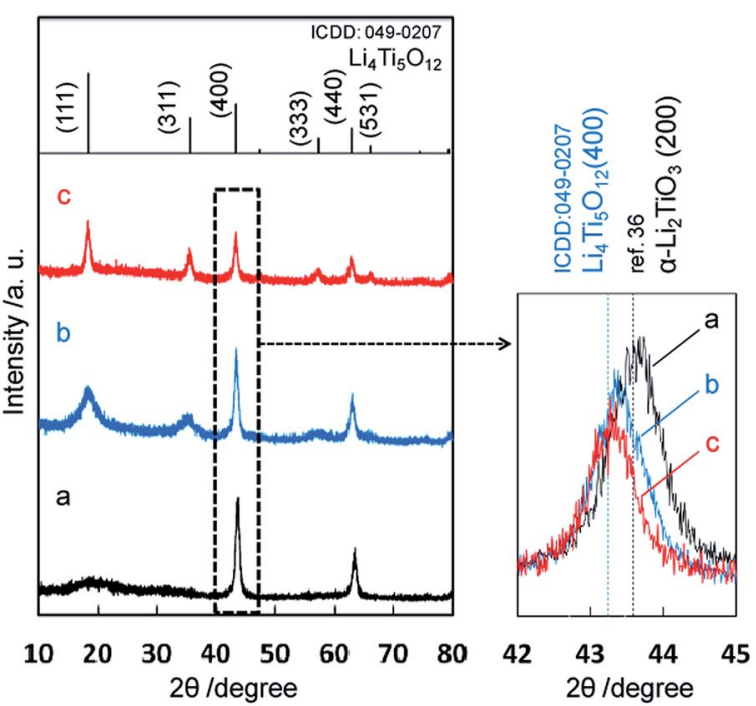

Fig. 1 XRD patterns of precipitates obtained by method I. The precursor obtained in the first stage (a), the final product in the second step (b), and the final product after calcination at $500{ }^{\circ} \mathrm{C}$ for $3 \mathrm{~h}$ (c). The top of this figure shows a diffraction pattern of $\mathrm{Li}_{4} \mathrm{Ti}_{5} \mathrm{O}_{12}$ (ICDD: 049-0207). 
Fig. 1, the diffraction peak at $2 \theta=43.7^{\circ}$ from the intermediate phase was corresponding to $0.2075 \mathrm{~nm}$. This result supports that the $\mathrm{Li}-\mathrm{Ti}-\mathrm{O}$ precursor was not $\mathrm{Li}_{4} \mathrm{Ti}_{5} \mathrm{O}_{12}$. Several diffraction peaks (002), (200), (006) and (062) assigned to $\beta-\mathrm{Li}_{2} \mathrm{TiO}_{3}$ were not observed for the $\mathrm{Li}-\mathrm{Ti}-\mathrm{O}$ precursor. Thus, the intermediate phase was deduced to be nominal $\alpha-\mathrm{Li}_{2} \mathrm{TiO}_{3}$, namely some lithium defects in the $\alpha-\mathrm{Li}_{2} \mathrm{TiO}_{3}$.

The diffraction peaks of the final product after the second solvothermal step at a relatively low $\mathrm{pH}$ value (9-10) agreed with those of spinel $\mathrm{Li}_{4} \mathrm{Ti}_{5} \mathrm{O}_{12}$, although the diffraction bands corresponding to the (111) and (311) planes were broadened (Fig. 1b). The diffraction peak position $\left(2 \theta=43.3^{\circ}\right)$ of the final product, which corresponded to the spinel $\mathrm{Li}_{4} \mathrm{Ti}_{5} \mathrm{O}_{12}$, shifted from that of the $\mathrm{Li}-\mathrm{Ti}-\mathrm{O}$ precursor $\left(2 \theta=43.7^{\circ}\right)$. Moreover, the diffraction peaks of (020), (110), (-111), and (021) for $\beta-\mathrm{Li}_{2} \mathrm{TiO}_{3}$ were not observed in the range of $2 \theta=20-22^{\circ}$. Thus, we succeeded in the production of spinel $\mathrm{Li}_{4} \mathrm{Ti}_{5} \mathrm{O}_{12}$ from the $\mathrm{Li}-\mathrm{Ti}-\mathrm{O}$ precursor by the solvothermal method without subsequent heat treatment.

Table 1 shows various sizes of the obtained $\mathrm{Li}_{4} \mathrm{Ti}_{5} \mathrm{O}_{12}$ samples. The table includes the FWHM of the diffraction peaks, the crystalline domain sizes, $D_{(111)}$ and $D_{(400)}$, the particle sizes $D_{\text {TEM }}$ estimated by TEM, and the particle sizes $D_{\text {BET }}$ calculated from specific surface area, $D_{\mathrm{BET}}=6 /\left(S_{\mathrm{BET}} \rho\right)$. $\rho$ is the density of the $\mathrm{Li}_{4} \mathrm{Ti}_{5} \mathrm{O}_{12}$. The weak (111) signal of $\mathrm{Li}_{4} \mathrm{Ti}_{5} \mathrm{O}_{12}$ is deduced to be a lattice distortion in the [111] direction. In the second solvothermal step, $\mathrm{Li}_{4} \mathrm{Ti}_{5} \mathrm{O}_{12}$ was formed from $\alpha-\mathrm{Li}_{2} \mathrm{TiO}_{3}$ which was produced in the first step. The (400) plain of $\mathrm{Li}_{4} \mathrm{Ti}_{5} \mathrm{O}_{12}$ is inherited from the (200) plain of cubic $\alpha-\mathrm{Li}_{2} \mathrm{TiO}_{3}$ because of the agreement of their $d$-spacings. On the other hand, the (111) plane of $\mathrm{Li}_{4} \mathrm{Ti}_{5} \mathrm{O}_{12}$ would be gradually formed because no similar planes exist in the precursor phase. Thus, we observed a strong signal due to the highly ordered (400) plane and a relatively weak signal due to the disordered (111) plane.

Fig. 2 shows TEM images of the products. Round-shaped particles with a diameter of $c a .13 \mathrm{~nm}$ were observed for the Li-Ti-O precursor (Fig. 2a). Almost the same sized particles of $\mathrm{Li}_{4} \mathrm{Ti}_{5} \mathrm{O}_{12}$ crystal were obtained by the second step. The lattice fringes corresponding to the (111) plane of $\mathrm{Li}_{4} \mathrm{Ti}_{5} \mathrm{O}_{12}$ support that the crystalline nanoparticles were generated by the second step (Fig. 2b). The crystalline domain sizes calculated by the Scherrer equation are $D_{(111)}=2.7 \mathrm{~nm}$ (as-prepared sample), $D_{(400)}=13.0 \mathrm{~nm}$ (as-prepared sample), $D_{(111)}=10.2 \mathrm{~nm}$ (calcined sample), and $D_{(400)}=14.9 \mathrm{~nm}$ (calcined sample). The value of $D_{(400)}=13.0 \mathrm{~nm}$ for the as-prepared sample was almost

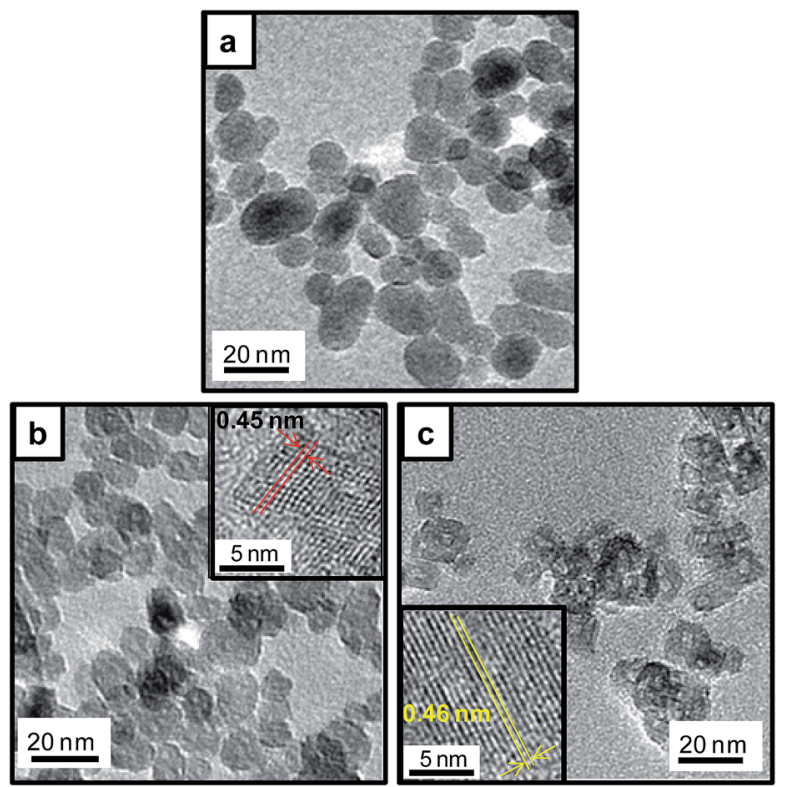

Fig. 2 TEM images of the precipitates obtained by method I. The precursor obtained in the first stage (a), the final product in the second step (b), and the final product after calcination at $500^{\circ} \mathrm{C}$ for $3 \mathrm{~h}$ (c). The insets in (b) and (c) show the lattice fringes of the (111) plane of $\mathrm{Li}_{4} \mathrm{Ti}_{5} \mathrm{O}_{12}\left(d_{(111)}=0.48 \mathrm{~nm}\right)$.

corresponded to the particles size $D_{\mathrm{TEM}}=11.7 \mathrm{~nm}$ observed by TEM. On the other hand, the value of $D_{(111)}$ was smaller than

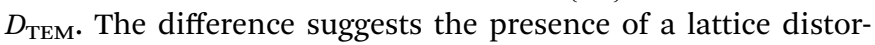
tion in the [111] direction. Because $D_{(111)}$ was clearly increased by the calcination, the crystallinity of the calcined sample is better than that of the as-prepared sample.

Here we discuss the formation mechanism of the spinel phase under the solvothermal conditions (Formulas (1)-(3)). Amorphous titanium dioxide was precipitated through a hydrolysis of bis(ammonium lactate) titanium dihydroxide under a basic condition before the first solvothermal step. The $\mathrm{Li}-\mathrm{Ti}-\mathrm{O}$ precursor, nominal $\alpha-\mathrm{Li}_{2} \mathrm{TiO}_{3}$, then formed under a basic condition over $\mathrm{pH} 11$ in the first solvothermal step. In the previous study, the transformation of the $\mathrm{Li}-\mathrm{Ti}-\mathrm{O}$ precursor to $\mathrm{Li}_{4} \mathrm{Ti}_{5} \mathrm{O}_{12}$ requires heat treatment at temperatures above $400{ }^{\circ} \mathrm{C}$. On the other hand, $\alpha-\mathrm{Li}_{2} \mathrm{TiO}_{3}$ is delithiated even at room temperature in pure water or an acid solution. ${ }^{14,36}$ Thus, $\left(\mathrm{Li}_{2-x} \mathrm{H}_{x}\right) \mathrm{TiO}_{3}$ could be formed through delithiation of the precursor by lowering the $\mathrm{pH}$ to $\sim 10$ by the addition of acetic

Table 1 FWHM of the diffraction peaks, the crystalline domain sizes $D_{(h k l)}$, the particle sizes $D_{\text {TEM }}$ observed by TEM, the particle sizes $D_{\text {BET }}$ calculated from specific surface area, and the specific surface areas $S_{\mathrm{BET}}$ for obtained $\mathrm{Li}_{4} \mathrm{Ti}_{5} \mathrm{O}_{12}$ samples. $D_{\mathrm{BET}}=6 /\left(\mathrm{S}_{\mathrm{BET}} \rho\right)$. $\rho$ is the density of the $\mathrm{Li}_{4} \mathrm{Ti}_{5} \mathrm{O}_{12}$

\begin{tabular}{lllccrrr}
\hline & FWHM $_{(111)} /$ degree & FWHM $_{(400)} /$ degree & $D_{(111)} / \mathrm{nm}$ & $D_{(400)} / \mathrm{nm}$ & $D_{\mathrm{TEM}} / \mathrm{nm}$ & $D_{\mathrm{BET}} / \mathrm{nm} S_{\mathrm{BET}} / \mathrm{m}^{2} \mathrm{~g}^{-1}$ \\
\hline Method I & & 0.71 & $2.7^{a}$ & 13.0 & $11.7(4.9)$ & 10.8 & 159.1 \\
Method II & 2.97 & 0.72 & $3.9^{a}$ & 12.7 & $13.0(4.1)$ & 10.9 & 157.9 \\
Method I calcined & 2.07 & 0.63 & 10.2 & 14.9 & $11.7(3.3)$ & 12.7 & 134.8 \\
Method II calcined & 0.67 & 0.67 & 13.0 & 13.8 & $13.9(4.9)$ & 17.1 & 100.5
\end{tabular}

${ }^{a}$ These values are affected by the lattice distortion. 
acid in the second step. Finally, the spinel $\mathrm{Li}_{4} \mathrm{Ti}_{5} \mathrm{O}_{12}$ is produced by dehydration of $\left(\mathrm{Li}_{2-x} \mathrm{H}_{x}\right) \mathrm{TiO}_{3}$. $(x=1.2$ is confirmed for formation of the spinel $\mathrm{Li}_{4} \mathrm{Ti}_{5} \mathrm{O}_{12}$ ). When the $\mathrm{pH}$ value was decreased to below $\mathrm{pH} 9$ by the addition of a large amount of acetic acid, we observed the formation of anatase $\mathrm{TiO}_{2}$ through $\mathrm{H}_{2} \mathrm{TiO}_{3}$ due to excess delithiation. This fact supports the formation mechanism of the spinel phase in the solution system proposed here. When hydrochloric acid or nitric acid was used as a pH controller instead of acetic acid, spinel $\mathrm{Li}_{4} \mathrm{Ti}_{5} \mathrm{O}_{12}$ was also produced. These results support the role of the acid in the reaction.

$$
\begin{gathered}
2 \mathrm{LiOH}+\mathrm{TiO}_{2} \rightarrow \mathrm{Li}_{2} \mathrm{TiO}_{3}+\mathrm{H}_{2} \mathrm{O}(>\mathrm{pH} \text { 11) } \\
\mathrm{Li}_{2} \mathrm{TiO}_{3}+x \mathrm{H}^{+} \rightarrow\left(\mathrm{Li}_{2-x} \mathrm{H}_{x}\right) \mathrm{TiO}_{3}+x \mathrm{Li}^{+} \text {(delithiation) } \\
\left(\mathrm{Li}_{2-x} \mathrm{H}_{x}\right) \mathrm{TiO}_{3} \rightarrow \mathrm{Li}_{2-x} \mathrm{TiO}_{3-x / 2}+x / 2 \mathrm{H}_{2} \mathrm{O} \text { (dehydration) }
\end{gathered}
$$

\subsection{Basicity-controlled one-step two-phase method (method II)}

Based on the reaction process of the two-step solvothermal method mentioned above, a delithiation process induced by decreasing the basicity is essential for the formation of the spinel $\mathrm{Li}_{4} \mathrm{Ti}_{5} \mathrm{O}_{12}$ phase in the solution system. Next we developed the one-pot synthesis of the spinel $\mathrm{Li}_{4} \mathrm{Ti}_{5} \mathrm{O}_{12}$ nanocrystal with self-control of the basicity using the two-phase system of water-ethanol and toluene-oleic acid. As shown in Fig. 3, the pure spinel phase was directly obtained after the solvothermal reaction at $200{ }^{\circ} \mathrm{C}$ for $24 \mathrm{~h}$, whereas the $\mathrm{Li}-\mathrm{Ti}-\mathrm{O}$ precursor was observed for $12 \mathrm{~h}$. The Li-Ti-O precursor was produced under a relatively high $\mathrm{pH}$ condition due to the dissolution of lithium hydroxide in the initial stage. The $\mathrm{Li}_{4} \mathrm{Ti}_{5} \mathrm{O}_{12}$ crystals were then formed from the precursor by decreasing the basicity in the progressive stage. This means that a gradual transfer of a certain amount of the organic acid from the toluene phase

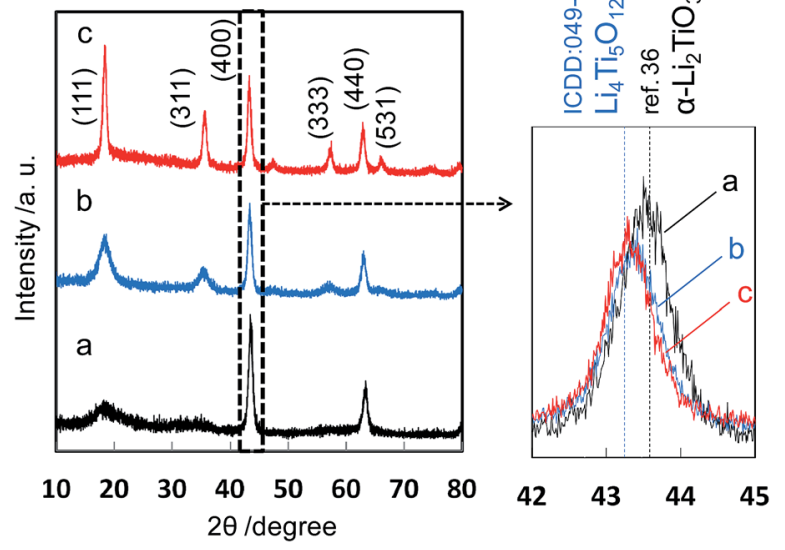

Fig. 3 XRD patterns of the precursor obtained by method II in the initial stage (12 h) (a), the $\mathrm{Li}_{4} \mathrm{Ti}_{5} \mathrm{O}_{12}$ crystals in the progressive stage (24 h) (b), and after calcination at $500{ }^{\circ} \mathrm{C}$ for $3 \mathrm{~h}$ (c). lowers the basicity of the water phase by disassociation. tertButylamine was needed for the two-phase solvothermal process because a slight amount of anatase $\mathrm{TiO}_{2}$ as an impurity formed without using tert-butylamine. The presence of tert-butylamine may support decreasing the $\mathrm{pH}$ stably or stabilizing titanium hydroxide ions as dissolution species. Additionally, the formation of the $\mathrm{Li}_{4} \mathrm{Ti}_{5} \mathrm{O}_{12}$ nanocrystal required a solvothermal temperature equal to or higher than $180{ }^{\circ} \mathrm{C}$ (Fig. S2 $\dagger$ ). The particle size and the specific surface area of the products were ca. $13 \mathrm{~nm}$ (Fig. 4) and $158 \mathrm{~m}^{2} \mathrm{~g}^{-1}$, respectively. The crystallinity was improved by calcination at $500{ }^{\circ} \mathrm{C}$ with a slight increase in the particle size.

\subsection{Electrochemical analyses of $\mathrm{Li}_{4} \mathrm{Ti}_{5} \mathrm{O}_{12}$ nanocrystals}

The electrochemical performance was measured for the Li-Ti-O precursor and $\mathrm{Li}_{4} \mathrm{Ti}_{5} \mathrm{O}_{12}$ nanocrystals obtained through methods I and II. The samples calcined at $500{ }^{\circ} \mathrm{C}$ were also characterized under the same conditions. Fig. 5 and 6 show charge-discharge curves and the cycle and rate performances, respectively, at several current rates in the voltage between 1.0 and $2.7 \mathrm{~V}$. We observed unclear voltage plateaus and low capacity values for the $\mathrm{Li}-\mathrm{Ti}-\mathrm{O}$ precursor (a) and the calcined one $\left(\mathrm{a}^{\prime}\right)$. On the other hand, the $\mathrm{Li}_{4} \mathrm{Ti}_{5} \mathrm{O}_{12}$ nanocrystals obtained by method I (b) showed a reaction voltage plateau around $1.55 \mathrm{~V}\left(v s . \mathrm{Li} / \mathrm{Li}^{+}\right)$, and the first discharge and reversible capacity were 113 and $102 \mathrm{~mA} \mathrm{~h}$ $\mathrm{g}^{-1}$, respectively, at $0.20 \mathrm{C}\left(1.0 \mathrm{C}=175 \mathrm{~mA} \mathrm{~g}^{-1}\right)$. The first reversible capacity of the nanocrystals was increased to $128 \mathrm{~mA} \mathrm{~h}$ $\mathrm{g}^{-1}$ by the calcination $\left(\mathrm{b}^{\prime}\right)$. The capacity of the $\mathrm{Li}_{4} \mathrm{Ti}_{5} \mathrm{O}_{12}$ crystals

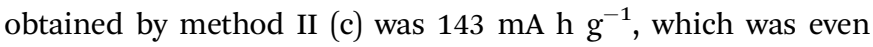
higher than that of the calcined one $\left(\mathrm{c}^{\prime}\right)\left(137 \mathrm{~mA} \mathrm{~h} \mathrm{~g}^{-1}\right)$ and was comparable to the results of well-crystallined $\mathrm{Li}_{4} \mathrm{Ti}_{5} \mathrm{O}_{12}$ reported in a previous article. ${ }^{15}$ These results indicate that the $\mathrm{Li}_{4} \mathrm{Ti}_{5} \mathrm{O}_{12}$ nanocrystals obtained directly by method II showed a good capacity even without heat treatment. The capacity value of asprepared $\mathrm{Li}_{4} \mathrm{Ti}_{5} \mathrm{O}_{12}$ nanocrystals (b and c) was decreased by increasing the rate current. On the other hand, the performance of the $\mathrm{Li}_{4} \mathrm{Ti}_{5} \mathrm{O}_{12}$ nanocrystals was improved by the subsequent calcination $\left(\mathrm{b}^{\prime}\right.$ and $\left.\mathrm{c}^{\prime}\right)$. A high crystallinity would be required for a fast electrode reaction at a high rate. Because the difference in the crystallinity of the calcined samples is smaller than that of the as-prepared samples, the difference in reversible capacity of the calcined samples obtained method I and II was decreased. According to the difference of $\mathrm{FWHM}_{(111)}\left(2.97^{\circ}\right.$ (method I) and
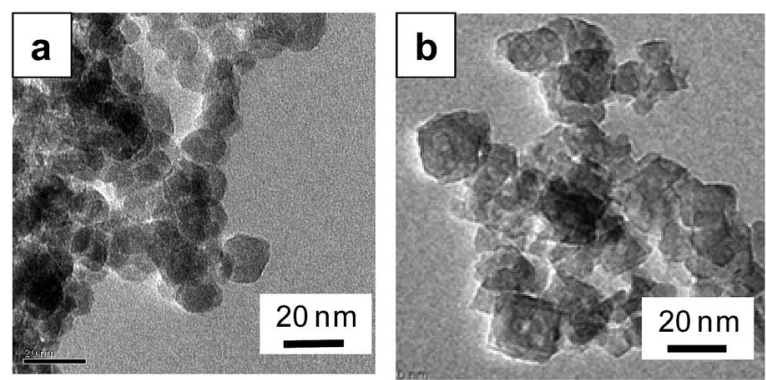

Fig. 4 TEM images of the $\mathrm{Li}_{4} \mathrm{Ti}_{5} \mathrm{O}_{12}$ crystals prepared by method II (a) and after calcination at $500{ }^{\circ} \mathrm{C}$ for $3 \mathrm{~h}$ (b). 

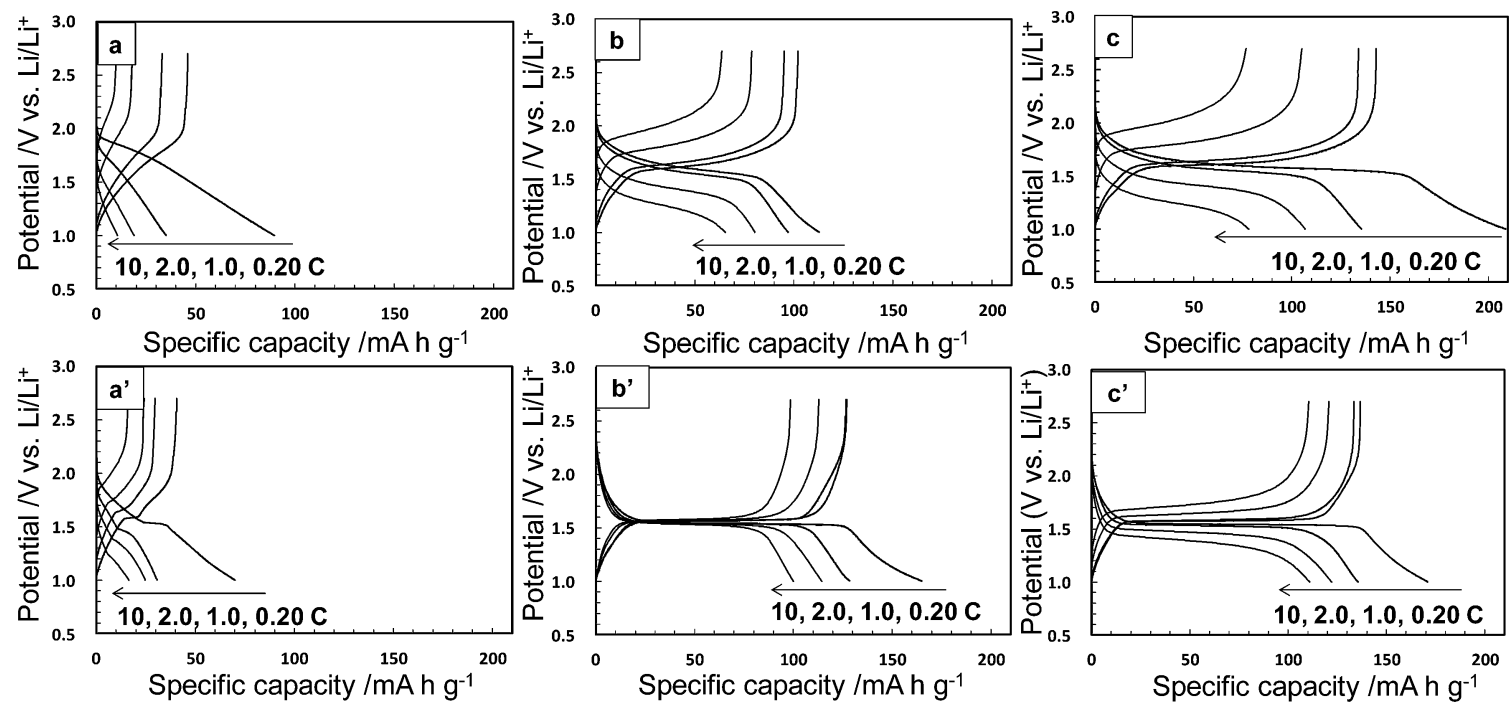

Fig. 5 Charge-discharge curves at various current rates $\left(1.0 \mathrm{C}=175 \mathrm{~mA} \mathrm{~g}^{-1}\right)$ of the $\mathrm{Li}-\mathrm{Ti}-\mathrm{O}$ precursor $(\mathrm{a})$, the $\mathrm{Li}_{4} \mathrm{Ti}_{5} \mathrm{O}_{12} \mathrm{nanocrystals}_{\mathrm{O}}$ obtained by methods I and II (b and C, respectively), and the calcined samples at $500{ }^{\circ} \mathrm{C}$ for $3 \mathrm{~h}\left(\mathrm{a}^{\prime}, \mathrm{b}^{\prime}\right.$, and $\left.\mathrm{c}^{\prime}\right)$.

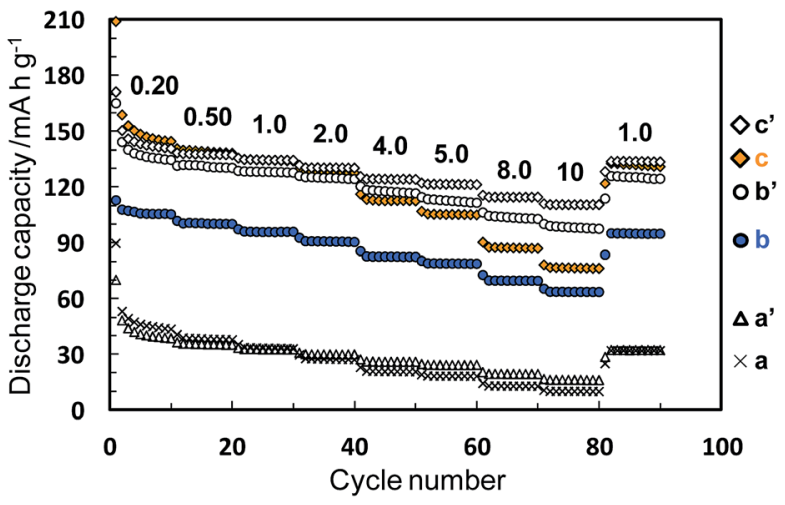

Fig. 6 Rate and cycle performances of the Li-Ti-O precursor (a), the $\mathrm{Li}_{4} \mathrm{Ti}_{5} \mathrm{O}_{12}$ nanocrystals obtained by methods I and II (b and $\mathrm{c}$, respectively), and the calcined samples at $500^{\circ} \mathrm{C}$ for $3 \mathrm{~h}\left(\mathrm{a}^{\prime}, \mathrm{b}^{\prime}\right.$ and $\left.\mathrm{c}^{\prime}\right)$. The numbers above the plots indicate current rates per $\mathrm{C}(1.0 \mathrm{C}=$ $175 \mathrm{~mA} \mathrm{~g}^{-1}$ ).

$2.07^{\circ}$ (method II)), the crystallinity of the as-prepared sample of method II was higher than that of method I. We think that the performance was not affected by tert-butylamine because the organic molecules were easily removed in the washing process. In the one-step process, the $\mathrm{Li}_{4} \mathrm{Ti}_{5} \mathrm{O}_{12}$ nanocrystals are directly formed through the transformation of the fresh precursor phase in the solution system. Thus, the higher crystalline products are easily obtained by this simple technique. At a low current rate (0.20-1.0 C), the performance of as-prepared $\mathrm{Li}_{4} \mathrm{Ti}_{5} \mathrm{O}_{12}$ nanocrystals by method II (c) was higher than that of the calcined one. The higher performance of the $\mathrm{Li}_{4} \mathrm{Ti}_{5} \mathrm{O}_{12}$ nanocrystals may be attributed to the coexistence of the high crystallinity and the high specific surface area due to loose aggregation without the calcination process. This suggests the advantage of direct synthesis of $\mathrm{Li}_{4} \mathrm{Ti}_{5} \mathrm{O}_{12}$ nanocrystals by the solvothermal method. Tailing was observed in the first discharge profiles $(0.20 \mathrm{C})$. According to ref.
34 , the irreversible capacity was ascribed to the surface reaction of nanosized $\mathrm{Li}_{4} \mathrm{Ti}_{5} \mathrm{O}_{12}$ samples. Therefore, the origin of tailing in the first discharge curves for our samples would be attributed to the presence of a high surface area originating form nanosized $\mathrm{Li}_{4} \mathrm{Ti}_{5} \mathrm{O}_{12}$ particles. In the previous works, the electrochemical performance of as-prepared sample obtained by the solvothermal method was quite lower than that of calcined samples due to their lower crystallinity. Highly crystalline products can be prepared even through the low-temperature process by adjusting the preparation conditions. The direct synthesis of the products exhibiting a high performance would enable a low-temperature technique which is needed such for low energy consumption process, fabrication of nanoscale textures, and surface modification with organic molecules.

\section{Conclusions}

Spinel $\mathrm{Li}_{4} \mathrm{Ti}_{5} \mathrm{O}_{12}$ nanocrystals were produced through the $\mathrm{pH}$ controlled two-step solvothermal process. We found that the formation of $\mathrm{Li}_{4} \mathrm{Ti}_{5} \mathrm{O}_{12}$ crystals requires the nucleation of the $\mathrm{Li}$ Ti-O precursor under a high $\mathrm{pH}$ condition in the initial stage and its transformation with a decrease of $\mathrm{pH}$ in the progressive stage of the solvothermal reaction. Then we succeeded in the direct synthesis of spinel $\mathrm{Li}_{4} \mathrm{Ti}_{5} \mathrm{O}_{12}$ nanocrystals by the one-step two-phase solvothermal process using a toluene-oleic acid system as a novel basicity-control method. The $\mathrm{Li}_{4} \mathrm{Ti}_{5} \mathrm{O}_{12}$ nanocrystals of $c a .13 \mathrm{~nm}$ in diameter prepared by the one-step two-phase solvothermal process showed a high specific capacity for application as an anode material.

\section{Acknowledgements}

This work was partially supported by the Advanced Low Carbon Technology Research and Development Program of Strategic 
Basic Research Programs from Japan Science and Technology Agency.

\section{Notes and references}

1 T. Ohzuku, A. Ueda and N. Yamamoto, J. Electrochem. Soc., 1995, 142, 1431-1435.

2 K. M. Colbow, J. R. Dahn and R. R. Haering, J. Power Sources, 1989, 26, 397-402.

3 K. Zaghib, M. Simoneau, M. Armand and M. Gauthier, J. Power Sources, 1999, 81-82, 300-305.

4 F. Ronci, P. Reale, B. Scrosati, S. Panero, V. R. Albertini, P. Perfetti, M. di Michiel and J. M. Merino, J. Phys. Chem. B, 2002, 106, 3082-3086.

5 H.-G. Jung, S.-T. Myung, C. S. Yoon, S.-B. Son, K. H. Oh, K. Amine, B. Scrosati and Y.-K. Sun, Energy Environ. Sci., 2011, 4, 1345-1351.

6 L. Kavan and M. Grätzel, Electrochem. Solid-State Lett., 2002, 5, A39-A42.

7 A. S. Prakash, P. Manikandan, K. Ramesha, M. Sathiya, J.-M. Tarascon and A. K. Shukla, Chem. Mater., 2010, 22, 2857-2863.

8 C. Jiang, E. Hosono, M. Ichihara, I. Honma and H. Zhou, J. Electrochem. Soc., 2008, 155, A553-A556.

9 L. Shen, C. Yuan, H. Luo, X. Zhang, K. Xu and Y. Xia, J. Mater. Chem., 2010, 20, 6998-7004.

10 Y. Tang, L. Yang, Z. Qui and J. Huang, J. Mater. Chem., 2009, 19, 5980-5984.

11 Y.-S. Lin and J.-G. Duh, J. Power Sources, 2011, 196, 1069810703.

12 D. Fattakhova and P. Krtil, J. Electrochem. Soc., 2002, 149, A1224-A1229.

13 A. Zhang, Z. M. Zheng, F. Y. Cheng, Z. L. Tao and J. Chen, Sci. China: Chem., 2011, 54, 936-940.

14 J. Lu, C. Nan, Q. Peng and Y. Li, J. Power Sources, 2012, 202, 246-252.

15 H. Yan, Z. Zhu, D. Zhang, W. Li and Qilu, J. Power Sources, 2012, 219, 45-51.

16 Y. F. Tang, L. Yang, Z. Qiu and J. S. Huang, Electrochem. Commun., 2008, 10, 1513-1516.

17 H. Cheng, J. Ma, Z. Zhao and L. Qi, Chem. Mater., 1995, 7, 663-671.
18 Q. Wu, X. Chen, P. Zhang, Y. Han, X. Chen, Y. Yan and S. Li, Cryst. Growth Des., 2008, 8, 3010-3018.

19 V. Subramanian, H. Zhu, R. Vajtai, P. M. Ajayan and B. Wei, J. Phys. Chem. B, 2005, 109, 20207-20214.

20 H.-X. Mai, L.-D. Sun, Y.-W. Zhang, R. Si, W. Feng, H.-P. Zhang, H.-C. Liu and C.-H. Yan, J. Phys. Chem. B, 2005, 109, 24380-24385.

21 C.-T. Dinh, T.-D. Nguyen, F. Kleitz and T.-O. Do, ACS Nano, 2009, 3, 3737-3743.

22 F. Lu, W. Cai and Y. Zhang, Adv. Funct. Mater., 2008, 18, 1047-1056.

23 G. Tian, Y. Chen, W. Zhou, K. Pan, Y. Dong, C. Tian and H. Fu, J. Mater. Chem., 2011, 21, 887-892.

24 A. Testino, M. T. Buscaglia, V. Buscaglia, M. Viviani, C. Bottino and P. Nanni, Chem. Mater., 2004, 16, 1536-1543.

25 M.-H. Um and H. Kumazawa, J. Mater. Sci., 2000, 35, 12951300.

26 W. Dong, G. Zhao, B. Song, G. Xu, J. Zhou and G. Han, CrystEngComm, 2012, 14, 6990-6997.

27 D.-S. Seo, H. Kim and J.-K. Lee, J. Cryst. Growth, 2005, 275, e2371-e2376.

28 C.-Y. Xu, Q. Zhang, H. Zhang, L. Zhen, J. Tang and L.-C. Qin, J. Am. Chem. Soc., 2005, 127, 11584-11585.

29 N. Masaki, S. Uchida and T. Sato, J. Mater. Chem., 2002, 12, 305-308.

30 M. Tomiha, N. Masaki, S. Uchida and T. Sato, J. Mater. Sci., 2002, 37, 2341-2344.

31 M. Sugita, M. Tsuji and M. Abe, Bull. Chem. Soc. Jpn., 1990, 63, 1978-1984.

32 D. Fattakhova, V. Petrykin, J. Brus, T. Kostlánová, J. Dědeček and P. Krtil, Solid State Ionics, 2005, 176, 1877-1885.

33 S.-H. Yu, A. Pucci, T. Herntrich, M.-G. Willinger, S.-H. Baek, Y.-E. Sung and N. Pinna, J. Mater. Chem., 2011, 21, 806-810.

34 A. Laumann, M. Bremholm, P. Hald, M. Holzapfel, K. T. Fehr and B. B. Iversen, J. Electrochem. Soc., 2012, 159, A166-A171.

35 A. Laumann, K. M. Ø. Jensen, C. Tyrsted, M. Bremholm, K. T. Fehr, M. Holzapfel and B. B. Iversen, Eur. J. Inorg. Chem., 2011, 2221-2226.

36 A. Laumann, K. T. Fehr, M. Wachsmann, M. Holzapfel and B. B. Iversen, Solid State Ionics, 2010, 181, 1525-1529. 